\title{
Diversity and production in an Afromontane Forest
}

\author{
Klaus v. Gadow ${ }^{1,2^{*}}$ (D), GongQiao Zhang ${ }^{3}$, Graham Durrheim ${ }^{4}$, David Drew ${ }^{1}$ and Armin Seydack ${ }^{4}$
}

\begin{abstract}
Background: This contribution evaluates the effect of forest structure and tree species diversity on plot productivity and individual tree growth in the unique Knysna forests in Southern Africa using mapped tree data from an observational study that has been re-measured over a period of 40 years.

Methods: The effects of tree species diversity and forest structure on tree growth and forest production are evaluated on three levels of resolution: a) the forest community (canopy, sub-canopy species), b) the subplots (number of trees per ha, skewness of the diameter distribution, diameter coefficient of variation) and c) the immediate neighborhood of selected reference trees ("Mingling", "Dominance", Aggregation" and "Size Variation").

Results: An analysis of the community level identified two distinct clusters, one including dominant/canopy species with the highest growth rates and a greater variation of growth, and another cluster which includes the remaining subcanopy species which have a smaller maximum size and lower rates of growth. The area-based structure variables on plot level have a highly significant effect on total basal area growth. However, the effects of forest density and species richness on productivity were not straight forward. Maximum basal area production of about $0.75 \mathrm{~m}^{2} / \mathrm{ha} /$ year is achieved at medium levels of richness (around 20 species per ha) and medium levels of density (around $30 \mathrm{~m}^{2} / \mathrm{ha}$ basal area) using percentile regression estimates. The relative "Dominance" of a selected reference tree had a highly significant effect on individual tree growth on all investigated species. Other neighbourhood structure variables were only occasionally significant or not significant at all.

Conclusion: This contribution presents a new theoretical framework for analysing natural forests that includes community, plot and neighborhood variables of forest structure and diversity, and a first specific analysis of the structure and dynamics of the Knysna Afromontane Forest, based on a unique set of longterm observations. The species-area (SAR) model developed in this study, represents a new general approach that can be used to derive a common standard of tree species diversity for different plot sizes, the species richness per hectare.
\end{abstract}

\section{Background}

Natural forests represent complex systems and the amount of information which is required to describe their structure and dynamics is a measure of their complexity. Multi-species forest communities represent a particular challenge if we wish to describe them in ways that are easy to comprehend, yet sufficiently detailed and comprehensive.

\footnotetext{
* Correspondence: kgadow@gwdg.de

${ }^{1}$ Georg-August University in Göttingen, Göttingen, Germany

${ }^{2}$ Department of Forestry and Wood Science, University of Stellenbosch,

Stellenbosch, South Africa

Full list of author information is available at the end of the article
}

\section{Structure and diversity}

Structure is a fundamental notion, an open-ended theme offering itself to interpretation within many disciplines of the sciences, arts and humanities (Pullan and Bhadeshia, 2000). Referring to specific patterns and relationships, structure may develop as a result of a planned design, or through a process of self-organization. Self-organisation involves competition and a variety of interactions between individual trees (Gadow et al., 2011). Thus, structure and diversity are important features of a particular forest community. Forest regeneration and competition for essential resources produce very specific structures which in turn generate particular processes of growth and regeneration (Sahney et al. 2010). Associated with a specific forest structure are particular patterns of diversity. 
According to Guillemot et al. (2014), the structure of a forest has strong effects on its functioning, and there is growing interest in understanding the link between forest structure and ecosystem services (Gamfeldt et al., 2013a,b). Based on an analysis of the US Forest Inventory and Analysis database, involving more than 20,000 plots, Caspersen and Pacala (2001) found a positive correlation between biomass productivity and species richness. Watson et al. (2015) compiled ground-measured data from approximately half a million forest inventory plots across the United States, Alaska, and northeastern China to map tree species richness, forest stocking, and productivity. Ninety-six percent of sample plots showed a significant positive effect of species richness on site productivity. This can be explained by the concurrent increase of productivity based on growing season length and species diversity towards lower latitudes. Also, on a global spatial scale, annual productivity and species richness/ diversity both increase towards the equator (Gillman et al. 2015). However, the increasing annual productivity is primarily the result of longer growing seasons in the tropics. A sufficiently clear understanding of the latitudinal species diversity gradient still requires further scientific scrutiny.

For tropical-type forests generally, such as the Knysna forests, Seydack (2000) identified three canopy layer occupation guilds: forest matrix occupants, canopy dominants and supra-canopy occupants (including emergents). Canopy dominants and supra-canopy species achieve their representation in the community by invading the forest matrix (forest matrix invaders). These matrix invading canopy species are often considered to be gap opportunists and are geared to occupy upper canopy positions. Physiologically, forest matrix occupants are persistence specialists (stress resistance) under the resource-responsive metabolic performance mode, underpinning persistance capacity and niche specialisation under tropical conditions (Seydack 2000; Seydack et al. 2011, 2012).

As demonstrated by Gentry (1982), most tropical tree species richness/diversity is contained in the group of relatively smaller-sized trees, i.e. represented in the guild of forest matrix specialists. In tropical-type forests the biggest trees are also the fastest growing trees (Clark and Clark 1999). Basal area stocking levels and gross basal area productivity are positively correlated (Seydack 2000). Forest patches invaded by forest matrix invading canopy species have high stocking levels, inter alia due to the additive basal area phenomenon and high productivity of large trees (Midgley et al. 2002). Productivity levels depend on the representation of upper canopy trees, whilst species diversity is contained in the forest matrix. Thus, a forest matrix patch with few upper canopy trees may have a relatively high species diversity, but will have low productivity levels. The interpretation of structure effects on productivity is accordingly complex since productivity in itself shapes structure.

\section{The Knysna Afromontane Forests}

The southernmost patches of Afromontane forest in Africa are found in the areas of Knysna and the Amatole mountains of South Africa. Covering an area of only 56,800 ha (Midgley et al., 1997), the Knysna forests are located south of the mountains between Humansdorp and Mossel Bay, at $34^{\circ} \mathrm{S}$ and between $22^{\circ}$ and $25^{\circ} \mathrm{E}$ and mainly below $520 \mathrm{~m}$ a.s.l.. The average annual maximum temperature for the region is about $19.2{ }^{\circ} \mathrm{C}$ while the average minimum is about $11.1^{\circ} \mathrm{C}$. Rainfall occurs in all seasons and the climate can be considered transitional to the tropical/subtropical and temperate regions. The mean annual precipitation may vary between 700 and $1230 \mathrm{~mm}$, subject to orographic influences and is increasing from west to east. These forests represent the largest indigenous forest complex of the country (Geldenhuys, 2012). The Amatole forests in the Eastern Cape region (at at $32.7^{\circ} \mathrm{S}$ and $27.2^{\circ} \mathrm{E}$ ) occur as a series of isolated patches with quite distinct floristic compositions with a total area estimated at 40,500 ha (Castley, 2001). Most tree species are of tropical origin, except some members of an older local non-tropical floral kingdom, e.g. Platylophus trifoliatus and Cunonia capensis which are also successful (von Breitenbach, 1974; van der Merwe, 1998). These forests are characterized by a rich variety of bryophytes, ferns, epiphytic lichens and orchids (Geldenhuys and MacDevette, 1989).

According to White (1983), the Knysna-Amatole forests represent an archipelago-like ecoregion and form the southernmost and largest extent of the afromontane forest in the region (see also Low and Rebelo, 1996). The ecoregion was identified by WWF and IUCN (1994) as an Afromontane Regional Center of Plant Diversity.

\section{Objectives}

Diversity does not only refer to species richness, but to a range of phenomena that determine the heterogeneity within a community, including the diversity of tree sizes and spatial patterns. In general, studies on complex multi-species and highly structured forest ecosystems, such as the Knysna-Amatole forests are relatively scarce (Midgley et al. 2002, Midgley \& Seydack 2006, Seydack et al. 2011 and Seydack et al. 2012). Structure and species diversity are important characteristics of a forest community and a comprehensive description regarding these attributes of the unique Knysna forests is still incomplete. Accordingly, the objective of this contribution is to describe the structure and diversity at community, plot and individual tree level, and to evaluate effects on individual tree growth and plot production. 


\section{Methods}

This study investigates forest production and to avoid misunderstanding, we first need to clarify our interpretation regarding the terms growth and production. Increment and growth are used to express an increase in tree size. These two terms have sometimes also been used to quantify total production of a forest community per unit area, which may be confusing, especially when a forest community consists of multiple species, tree dimensions and spatial arrangements. For this reason, it appears more logical to use the term production for the areabased increase of tree biomass, volume or basal area (where volume and basal area are often used as surrogates for biomass).

\section{The FVC permanent monitoring and research area}

The French Volume Curve (FVC) research areas were established in 1937 on Diepwalle State Forest (located to the north of the southern coastal town of Knysna in South Africa, at $33^{\circ} 56^{\prime} \mathrm{S}, 23^{\circ} 09^{\prime} \mathrm{E}$ ) and used until 1954 for evaluating experimental management systems. No further treatments have been applied since that time. The current Diepwalle FVC Research Area forest dynamics monitoring project was initiated in the early 1970's by scientists of the Saasveld Indigenous Forests Research Centre of the South African Forest Research
Institute. All trees within the area with a diameter at breast height (dbh) of $10 \mathrm{~cm}$ and greater were numbered, the species identified and the diameters were measured and recorded. The point of measurement was permanently marked by means of a painted line (Van Daalen, 1991). Two sections of the larger FVC site, covering a total of 67.7 ha and containing more than 50,000 trees, have been re-measured periodically since 1972. The "FVC South" (Fig. 1) has a predominantly southerly aspect and covers a total area of 44.4 ha.

The second block known as "FVC North", with a predominantly northerly aspect, has a total area of 23.3 ha. The management and maintenance of these areas was taken over by the Directorate "Indigenous Forest Management" during the 1980's and was transferred to the South African National Parks (SANParks) in 2005 to become part of the Garden Route National Park.

This study was conducted in the Diepwalle FVC research area (517 $\mathrm{m}$ a.s.l.) where 15 tree species have been defined as being canopy or emergent (Seifert et al. 2014). The FVC areas have been subdivided into parallel longitudinal strips called virees. The virees are between 380 and $400 \mathrm{~m}$ long and about $30 \mathrm{~m}$ wide. The FVC South and North are subdivided into 27 and 19 virees respectively. The viree boundaries are marked in the field by cutlines through the undergrowth, with the viree

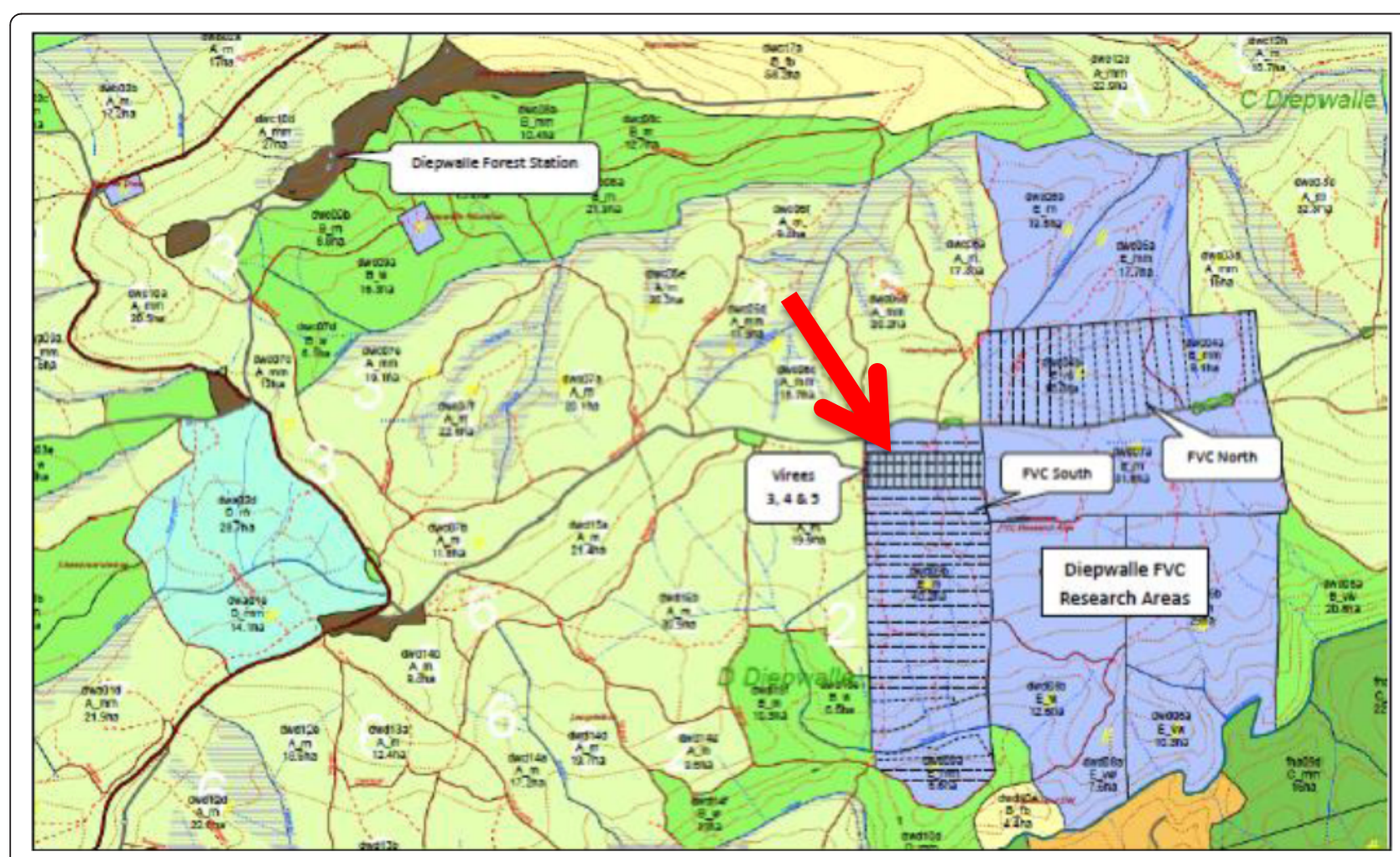

Fig. 1 Location of Diepwalle French Volume Curve (FVC) Research Areas, indicated in dark blue shading, showing areas used for forest dynamics monitoring projects. The block which includes virees 3, 4 and 5, used in this study, is indicated by the red arrow 
numbers painted on trees adjacent to the boundaries. During 1997 the virees were further subdivided into segments or parcels, making it possible to allocate the trees to different site types (based on slope and aspect) that do not correspond with the viree boundaries. The segments or parcels were mapped, but are not marked in the field. Tree positions have been plotted in some of the virees. The height of the main canopy is $18-22 \mathrm{~m}$ (Van Daalen, 1991).

The current analysis of FVC345, makes use of data from a contiguous block which includes virees 3,4 and 5 of the FVC South site, where all tree positions were mapped. Figure 2 shows the tree maps corresponding to the five enumerations between 1972 and 2007 in FVC345.

FVC345 was subdivided into 114 cells. The cell boundaries are visible in Fig. 1. This analysis represents a first attempt which uses these unique observations to improve our understanding of the structure and dynamics of this special ecosystem.

\section{Community structure}

The grouping of tree species into well-defined cohorts contributes to improved understanding of the functioning of a species-rich ecosystem (Picard et al., 2010). A high species diversity is usually associated with a scarcity of data for many species which are very common. A scarcity of data complicates or even impedes the development of models that might enable us to improve understanding of complex community dynamics. Aggregating species thus may facilitate modeling and provide a basis for sustainable use in a wider sense.

A popular method of species grouping is "size-growth ordenation" which involves the simultaneous consideration

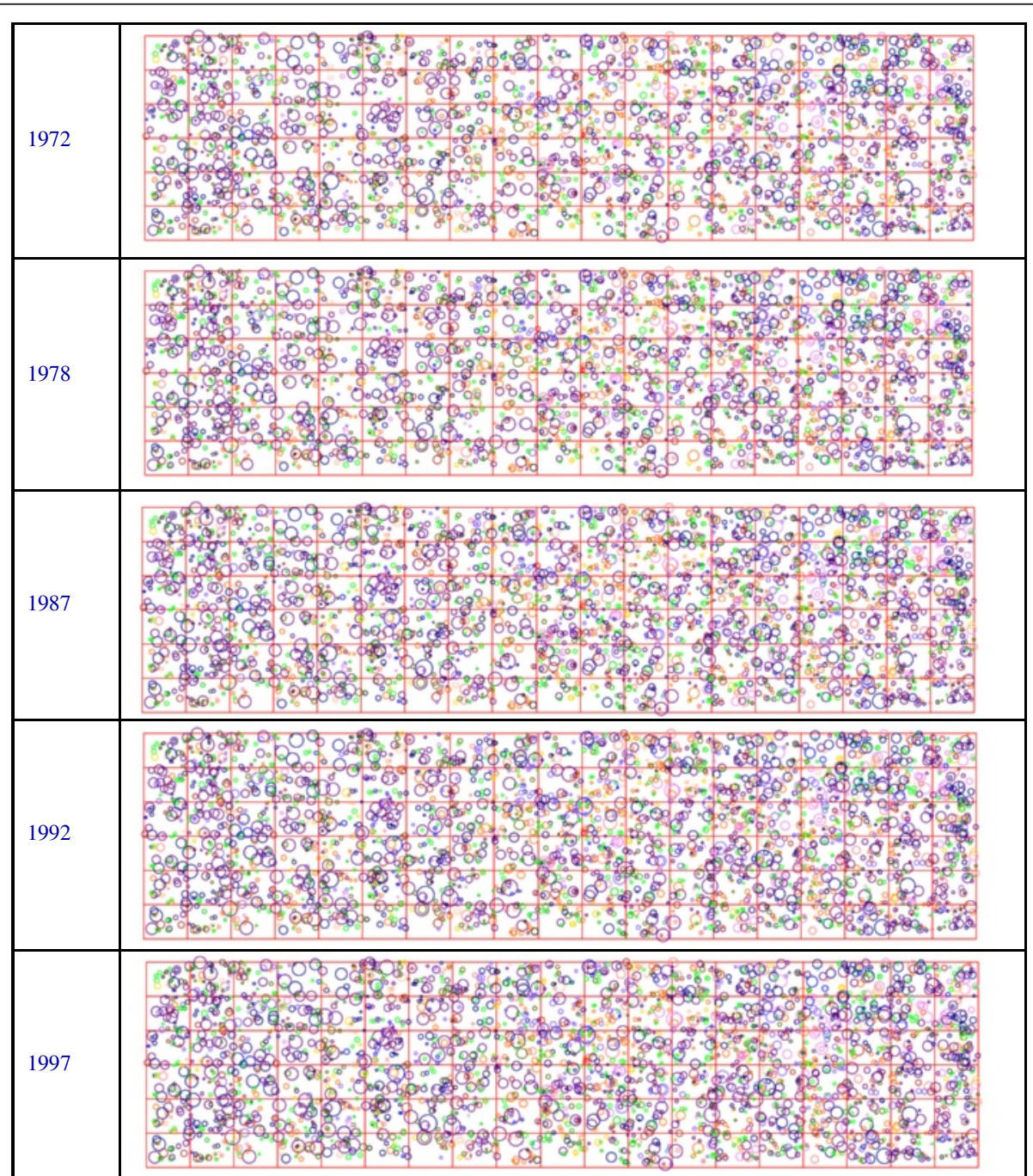

Fig. 2 Tree maps showing the tree locations of the contiguous observational study FVC345 for the five remeasurements 1972, 1978, 1987, 1992, 1997. Colours indicate tree species, circle radii tree dbh's 
of maximum tree size and average growth rate. Favrichon (1994) used size-growth ordenation, involving mean diameter and diameter increment, in a species grouping approach. Alder et al. (2002) presented a study involving an ordination of species' mean increment $\left(\mathrm{I}_{\mathrm{d}}\right)$ on the $95 \%$ percentile of the diameter distribution $\left(D_{95}\right)$, using a cluster analysis based on Euclidian distance between points. They compared growth rates and "typical size" for 204 tree species from permanent sample plots in Brazil, Costa Rica, Guayana and Papua New Guinea. Their clustering algorithm produced 16 centroids. Low growth rates associated with five of the 16 groups were assumed to be indicators of shade tolerance, had higher wood densities and typically occurred in a lower canopy or understorey position. Other groups had higher increment, and were light demanding with lower density timber. Alder et al. (2002) assigned names to specific group clusters, like "Pioneers", Emergents" or "Subcanopy Species" (see also Alder and Silva, 2000).

Following Lujan-Soto et al. (2015), we will use a bivariate mixture model to distinguish between different species clusters, based on maximum size (the mean of the $10 \%$ biggest diameter trees) and average diameter growth. The parameters are estimated using the R-function mclust (Fraley et al., 2012).

\section{Plot-based structure variables}

Area-based structure variables are used to describe a community within a defined plot area. Five area-based structure variables (density, crowding, richness, skewness and size variation) are used in this study and related to production (average increase of plot basal area). The five variables are described as follows:

- Density (BA): the measure of plot density used in this study is the sum of the cross-sectional areas of all trees per unit area. This quantity is known as the basal area and expressed in $\mathrm{m}^{2}$ per ha.

- Crowding (Nha): We define crowding as the number of trees per ha $(>10 \mathrm{~cm} \mathrm{DBH})$.

- Richness (Sha): Richness usually refers to the number of tree species per unit of an arbitrary plot area ha. We prefer to establish a common standard, the richness per ha. To achieve this, we first develop a species-area relation by calculating the mean richness values of sample plots with a radius of 3 to $60 \mathrm{~m}$. Each of these plot sizes were randomly positioned 100,000 times within the $380 \times 120 \mathrm{~m}$ study area. The 58 circle areas and associated average number of species were used to derive a species-area relationship (SAR) for the whole study area using the Chapman Richards model (Shifley and Brand, 1984):

$S=A *(1-\exp (-\mathrm{b} * \text { area }))^{\mathrm{c}}$ where $\mathrm{S}$ is richness, i.e. the number of species corresponding to the area in $\mathrm{m}^{2}$. Assuming two specific cases, a known richness $S_{1}$ observed in a plot with area $_{1}$ :

$$
S_{1}=A *\left(1-\exp \left(-\mathrm{b} * \operatorname{area}_{1}\right)\right)^{\mathrm{c}}
$$

and an estimated richness $S_{2}$ for a plot with area $_{2}$

$$
S_{2}=A *\left(1-\exp \left(-\mathrm{b} * \operatorname{area}_{2}\right)\right)^{\mathrm{c}}
$$

Solving (2) for the asymptote A:

$$
A=\frac{S_{1}}{\left(1-\exp \left(-\mathrm{b} * \text { area }_{1}\right)\right)^{\mathrm{c}}}
$$

and substituting the right hand side of equation (4) in (2), we obtain the following equation that can be used to estimate species richness $S_{2}$ for a plot with area $a_{2}$ if the richness $S_{1}$ in a plot with area ${ }_{1}$ is known:

$$
S_{2}=S_{1} \frac{\left(1-\exp \left(-\mathrm{b} * \mathrm{area}_{2}\right)\right)^{\mathrm{c}}}{\left(1-\exp \left(-\mathrm{b} * \operatorname{area}_{1}\right)\right)^{\mathrm{c}}}
$$

- Skewness (skew): Skewness describes the asymmetry of the probability distribution of tree diameters about the mean, calculated as Pearson's moment coefficient of skewness (Eq 6) which is based on the 2nd and 3rd moments.

$$
b_{1}=\frac{m_{3}}{m_{2}{ }^{3 / 2}}
$$

A negative skewness value (representing a leftskewed or left-tailed distribution) is characterized by an extended left tail while the mass of the distribution is concentrated to the right of the mean value. Accordingly, a positive skewness value indicates a distribution with an extended right tail.

- Size Variation (CV): The coefficient of variation of tree diameters (dbh's) is equal to the standard deviation of dbh's divided by the mean of the dbh distribution.

\section{Neighborhood structure}

Tree-based structure refers to the unique neighborhood constellation in the immediate vicinity of a specific tree. We will use the following four variables to describe the neighborhood structure of a reference tree and its four nearest neighbors:

- Mingling (M) describes the diversity of species within close proximity to the reference tree, and is equal to the proportion of the four nearest 
neighboring trees of a selected reference tree that belong to a species different from the reference tree.

- Dominance (D) describes the competitive status of the reference tree relative to neighbouring trees and is quantified as the proportion of the four nearest neighbors to a selected reference tree that are smaller than the reference tree.

- Aggregation (W) describes the spatial distribution, or specifically the level of "clustering" of trees nearest to the reference tree, expressed as the number of angles between pairs of neighbours that are smaller than some standard angle. We define the standard angle to be $360 /(n+1)$ where $n$ is the number of neighbors.

- Size Variation (CV) describes the variability of tree sizes, and is expressed by the coefficient of variation of the dbh's of all trees in the neighborhood group, including the reference tree.
Detailed descriptions of these variables have been published in numerous studies (see, for example Gadow (1993, 1999); Pommerening (1997); Aguirre et al. (2002); Pommerening (2002); Corral-Rivas et al. (2010); Hui et al. (2011); Gadow et al. (2011); Ni et al. (2014). Thus, we believe that this brief description will suffice. Four neighbours were found to be most suitable based on practical considerations in connection with the field assessment (Albert 1999; Hui and $\mathrm{Hu}, 2001$ ). A summary of the different possible constellations for any reference tree is presented in Fig. 3.

The relation between the basal area growth of individual trees and the four structure variables are evaluated for all species which are represented by at least 50 individuals. These species are Olea capensis ssp macrocarpa, Podocarpus latifolius, Ocotea bullata, Gonioma kamassi, Apodytes dimidiata, Curtisia dentata, Elaeodendron croceum, Nuxia floribunda and Pterocelastrus tricuspidatus.

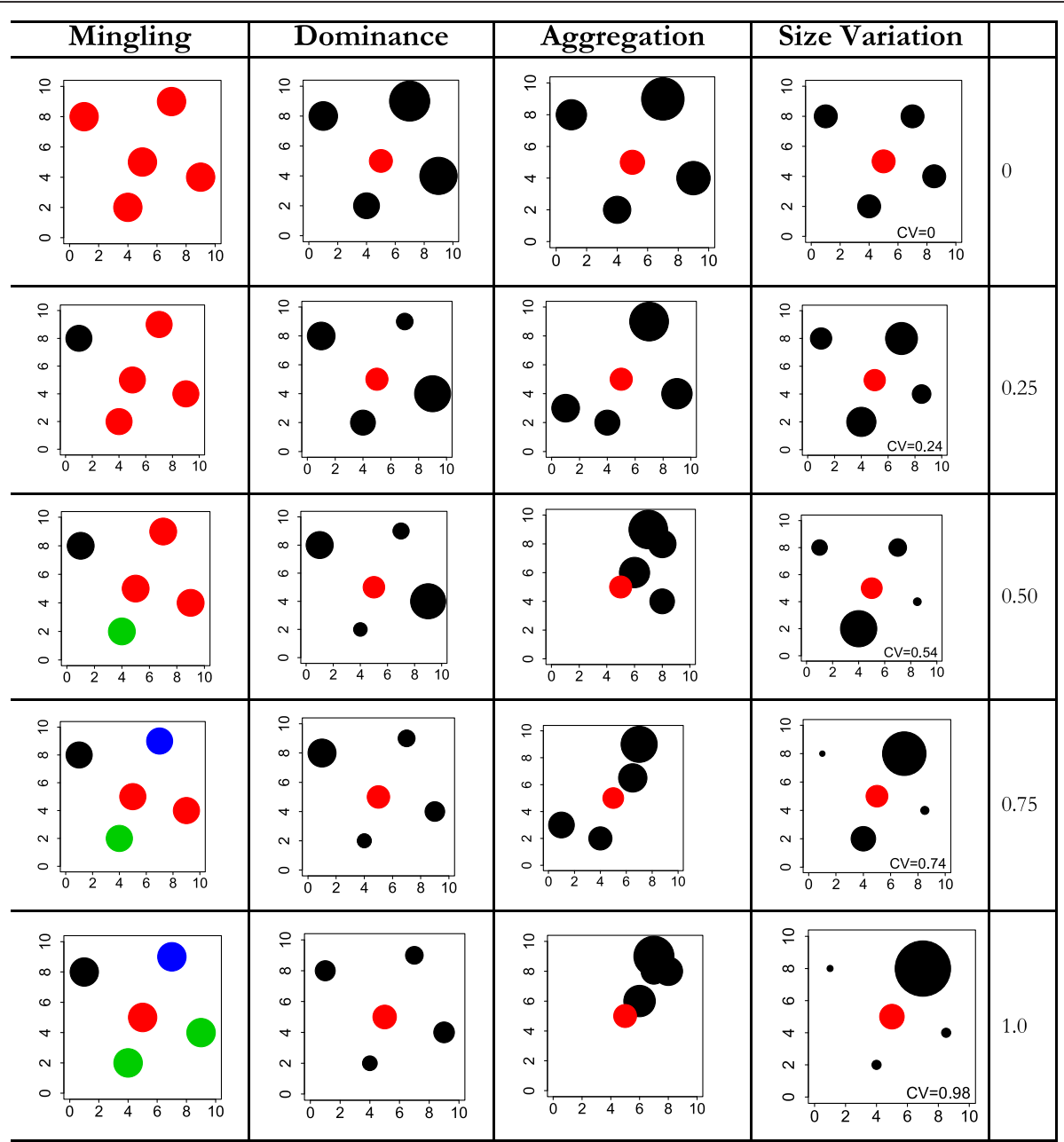

Fig. 3 The four structure variables used in this study (Mingling, Dominance, Aggregation and Size Variation). Each variable may assume five discrete values which gives $5^{4}=625$ possible neighborhood constellations for a given reference tree 


\section{Results}

The results are presented in three sections. First, we present the results of the community structuring approach. We then show the effect of area-based structure variables on forest production. Finally, we show the response of individual tree growth rates to the four tree-based structure variables.

\section{Community structure}

Table 1 presents a summary of the results of the community structuring approach. The mean tree basal area increment $\left(\mathrm{cm}^{2} /\right.$ year) and the mean of the $10 \%$ biggest diameter trees $(\mathrm{cm})$ are presented for the nine species that are represented by at least 50 individuals.

Figure 4 shows two distinct clusters, one including the four dominant species Olea capensis ssp. macrocarpa, Pterocelastrus tricuspidatus, Ocotea bullata and Podocarpus latifolius, the other including the five subdominant species Gonioma kamassi, Apodytes dimidiata, Curtisia dentata, Elaeodendron croceum and Nuxia floribunda.

The codes in Table 1 are used to identify the species in the graph. These four species have higher growth rates and also a greater variation of growth rates, ranging between about 5 and $9 \mathrm{~cm}^{2} /$ year mean basal area increment. The second cluster includes the remaining five species which have a smaller maximum size and lower rates of growth ranging between about 2 and $3.5 \mathrm{~cm}^{2} /$ year mean basal area increment.

\section{New SAR model}

The SAR model (1) provides a good fit with empirical parameters

$$
\begin{aligned}
\mathrm{A} & =25.8 * * * ; \mathrm{b}=-0.0002819 * * * \text { and } \mathrm{c} \\
& =0.3586 * * *
\end{aligned}
$$

Table 1 Mean basal area increment (iba, $\mathrm{cm}^{2} /$ year) and mean of the $10 \%$ biggest diameter trees $(\operatorname{maxd} 72, \mathrm{~cm})$ for nine species that are represented by at least 50 individuals

\begin{tabular}{lllcc}
\hline code & Species & iba & maxD72 & Group \\
\hline WP & Apodytes dimidiata & 2.91 & 37.4 & 2 \\
Saf & Elaeodendron croceum & 2.34 & 28.7 & 2 \\
Ass & Curtisia dentata & 3.41 & 30.9 & 2 \\
Kam & Gonioma kamassi & 1.82 & 20.0 & 2 \\
V & Nuxia floribunda & 2.34 & 33.9 & 2 \\
SH & Ocotea bullata & 5.27 & 45.9 & 1 \\
YH & Olea capensis macrocarpa & 8.70 & 51.5 & 1 \\
Geel & Podocarpus latifolius & 5.33 & 50.5 & 1 \\
Kers & Pterocelastrus tricuspidatus & 6.72 & 39.1 & 1 \\
\hline
\end{tabular}

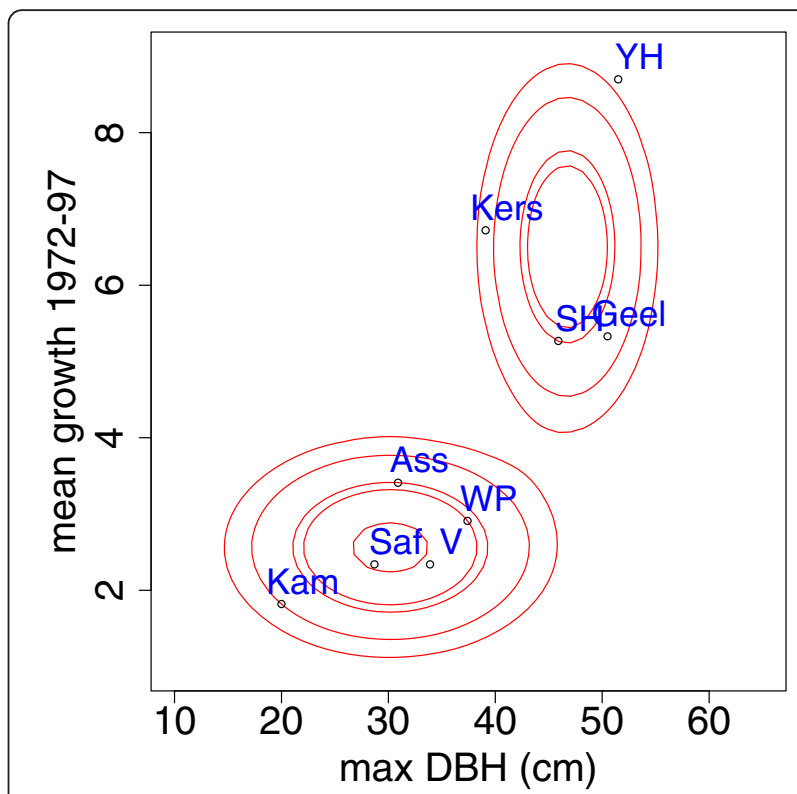

Fig. 4 Grouping of tree species based on maximum size (mean dbh of the $10 \%$ biggest trees) and average growth rate (mean basal area growth, $\mathrm{cm}^{2}$ /year) during the 25-year measurement interval 1972-1997

The residual standard error is 1.541 on $57^{\circ}$ of freedom. This model represents a new estimate of the tree species diversity for different plot sizes in the Diepwalle FVC study area. In addition, the new concept "richness per ha" (Sha) may be used as a measure of richness that is independent of the sample plot area. Sha is in some way comparable to the common standards basal area per ha and number of trees per ha. Sha may be used as a common standard to facilitate comparison among different ecosystems with varying degrees of species richness. For example, assuming that 12 species were observed on a $400 \mathrm{~m}^{2}$ sample plot, the number of species per ha is estimated at 26.2, using eq (5) with the three empirical parameters presented above.

\section{Effect of area-based structure variables on production}

Three structure variables Crowding (Nha), skewness (skew) and diameter coefficient of variation (CV) are highly and significantly associated with the per hectare production expressed here by the average basal area increment during the period 1972 to 1997 (iG72_97). The following linear model was obtained for the 25-year interval from 1972 to 1997 :

$$
\begin{aligned}
\mathrm{iG72}_{97}= & 0.1378(\mathrm{CV})-0.08226(\text { Skew }) \\
& +0.0002565(\mathrm{Nha})
\end{aligned}
$$

The residual standard error is 0.1029 on $111^{\circ}$ of freedom, and the multiple R-squared is 0.85 . The coefficient for diameter skewness is negative which means that $\mathrm{iG}$ over the 25 year period is reduced if skewness values are 
positive. Negative skewness implies a high proportion of large trees in the subplot which results in significantly greater production.

\section{Maximum production as related to density and richness}

Richness and density seem to have similar patterns of association in respect of maximum basal area production. Neither exhibits a clear relationship with production, whereas both show a distinct frontier. Below those bounds, there is great variation of production rates for different levels of density and richness caused by other unknown factors. Figure 5 presents the two frontiers, estimated by a non-linear percentile regression for the 0.99 quantile. Plot densities vary between about 10 and $50 \mathrm{~m}^{2} / \mathrm{ha}$, and maximum production is estimated at about $25 \mathrm{~m}^{2} /$ ha.

The number of tree species varies between 10 and 30 per ha in the subplots, and maximum basal area production is observed at medium levels of richness (around 22 species per ha).

\section{Nearest neighbour structure and tree growth}

The relationships between tree-based structural variables and basal area increment $\mathrm{cm}^{2}$ /year during the 25-year period 1972 to 1997 and the four structure variables are presented in Table 2. The relations are expressed by the coefficients of a multiple linear regression, for the ten most common species, which are represented by at least 50 individuals. All unlikely observations with negative growth rates were disregarded. The results are listed in Table 2.

The variable Dominance (D) is significant in all species, although only at alpha $=0.05$ in the case of Nuxia floribunda. Mingling (M) is significant or highly significant in three subcanopy specialists with relatively low growth rates (Gonioma kamassi, Curtisia dentata, Elaeodendron croceum). Aggregation (W) has a significant positive effect on the growth of Pterocelastrus tricuspidatus and Gonioma kamassi, but the effect is negative for Ocotea bullata, a species which tends to coppice from existing root stocks. Basal area increment was not sigifnicantly affected by Size variation (CV) in any species except Podocarpus latifolius.

\section{Discussion}

This study presents a general framework for analysing complex forests structures and represents a first detailed analysis of the effects of structure in the Knysna Afromontane forests at community, plot and individual tree level.

\section{Community structure}

A logical first approach to identify species groups is based on the premise that a forest community forms distinct vertical layers. Accordingly, Bossel and Krieger (1994) classified species as understorey, "treelets", canopy trees, emergents and pioneers. In a two-stage approach Köhler et al. (2000) classified species by potential height and successional status. Foresters have traditionally identified canopy and subcanopy species and such "layer" approaches are based on common sense. Seydack (2000) developed a model identifying canopylayer guilds for tropical-type forests involving two main canopy layer occupation guilds: forest matrix persistence specialists (subcanopy species, lower canopy species and relatively smaller-sized non-dominant canopy species) and forest matrix- invading growth productivity generalists (canopy/upper canopy/supra-canopy dominants/ occupants). Forest matrix specialist species are associated with growth-rate dependent vertical growth and stress
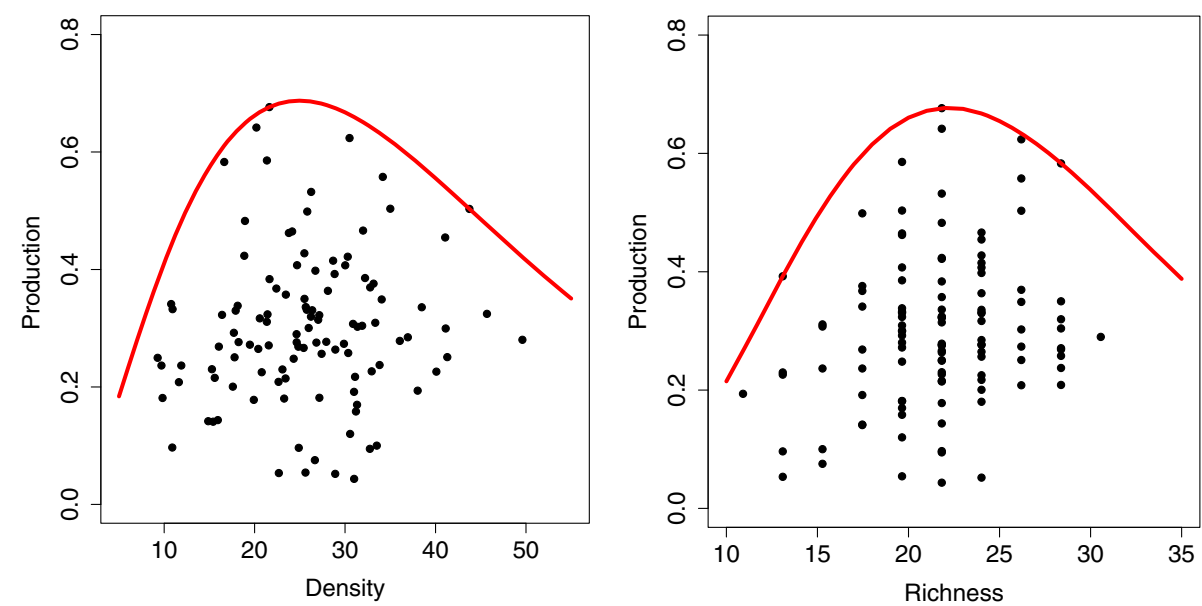

Fig. 5 Effects of initial Basal Area ( $m^{2}$ per ha, left) and Richness (expressed as number of tree species per ha, right) on the production (average basal area increment, $\mathrm{m}^{2} / \mathrm{ha} /$ year) assessed during the period 1972 to 1997 . The lines, calculated by a 0.99 nonlinear percentile regression, represent an estimate of the maximum production for different levels of richness and density 
Table 2 Relationship between by the basal area increment $\mathrm{cm}^{2} /$ year during the 25-year period 1972 to 1997 and the four structure variables (symbols defined previously), expressed by the coefficients of a multiple linear regression, for the ten most common species, represented by at least 50 individuals. RSE = residual standard error; iba = average basal area increment $\mathrm{cm}^{2} /$ year

\begin{tabular}{|c|c|c|c|c|c|c|c|c|}
\hline Species & $\mathrm{N}$ & $\mathrm{iba}$ & M & $\mathrm{D}$ & W & $\mathrm{T}$ & RSE & $R^{2}$ \\
\hline Apodytes dimidiata & 124 & 2.9 & $0.8420 \mathrm{~ns}$ & $3.333^{c}$ & $0.8156 \mathrm{~ns}$ & $0.3424 \mathrm{~ns}$ & 3.089 & 0.51 \\
\hline Elaeodendron croceum & 125 & 2.3 & $1.9731^{b}$ & $3.1575^{c}$ & $-0.5256 \mathrm{~ns}$ & $-0.1873 \mathrm{~ns}$ & 1.748 & 0.67 \\
\hline Curtisia dentata & 303 & 3.4 & $1.4611^{\mathrm{a}}$ & $3.389^{c}$ & $-0.1106 \mathrm{~ns}$ & $1.131 \mathrm{~ns}$ & 3.015 & 0.58 \\
\hline Gonioma kamassi & 379 & 1.8 & $1.205^{c}$ & $0.9251^{c}$ & $0.6956^{\mathrm{a}}$ & $0.3578 \mathrm{~ns}$ & 1.383 & 0.63 \\
\hline Nuxia floribunda & 53 & 2.3 & $0.5292 \mathrm{~ns}$ & $1.762^{\mathrm{a}}$ & $0.6324 \mathrm{~ns}$ & $1.221 \mathrm{~ns}$ & 1.736 & 0.68 \\
\hline Ocotea bullata & 82 & 5.3 & $-0.3746 \mathrm{~ns}$ & $6.6231^{b}$ & $-7.1909^{\mathrm{a}}$ & 5.3022 ns & 6.027 & 0.53 \\
\hline Olea capensis macrocarpa & 569 & 8.7 & $-0.7417 \mathrm{~ns}$ & $11.87^{c}$ & $0.5479 \mathrm{~ns}$ & $2.824 \mathrm{~ns}$ & 7.538 & 0.63 \\
\hline Podocarpus latifolius & 292 & 5.3 & 0.4192 ns & $6.286^{c}$ & $-1.235 \mathrm{~ns}$ & $4.063^{b}$ & 3.957 & 0.69 \\
\hline Pterocelastrus tricuspidatus & 142 & 6.7 & 0.6504 ns & $7.1894^{c}$ & $5.0142^{\mathrm{a}}$ & 1.4604 ns & 5.010 & 0.68 \\
\hline
\end{tabular}

${ }^{\mathrm{a}}$ at alpha $=0.05 ;{ }^{\mathrm{b}}$ at alpha $=0.01 ;{ }^{\mathrm{C}}$ at alpha 0.001

resistance (persistence capacity) under the tropical-type resource responsive metabolic performance trade-off mode (Seydack et al. 2011, 2012). Conversely, forest matrix invading canopy species are associated with diameter growth productivity under the resourcebuffered metabolic performance trade-off mode more prominently suited to temperate zone conditions (Seydack et al. 2011, 2012). Tropical-type forests tend to have a substantial species rich forest matrix content, particularly Neotropical forests, whereas Southeast Asian and West African tropical forests have additional forest matrix-invader components, with substantially increased upper canopy contents (Whitmore 1991). In temperate forests, the forest matrix content is relatively low in relation to canopy content. A major problem is to differentiate between subcanopy species that exhibit different traits. Furthermore, there is an obvious problem of differentiating between mature and immature canopy species such that all individuals can be uniquely assigned to a specific group.

Cornelissen and Cornwell (2014) propose that plant species effects on ecosystem functions should be mapped onto the Tree of Life by analysing traits and phylogenies together, thus linking ecological and evolutionary information. Species traits which may explain differences in ecological strategy usually vary widely. Recent advances in assessing plant species for the traits that support certain strategies combined with genetic screening and bioinformatics could form the basis for developing molecular plant phylogenies that could be used to develop distinct species clusters for particular ecosystems. Such an advanced taxonomic approach of aggregating species shows promise for future studies.

The basic information for analysing traits and phylogenies together, in an attempt to link ecological and evolutionary information, is still lacking. Therefore, the size-growth ordenation approach used in this study was found suitable in identifying two distinct species groups.

\section{Area-based structure in subplots}

Five area-based structure variables were used to describe the community within a defined plot area, and to establish a relation with plot basal area production. Three of these variables, crowding, skewness and coefficient of variation of the diameter distribution have a highly significant effect. Crowding implies a relatively high growing stock of actively growing trees. Skewness reflects the presence of a proportionally higher presence of large trees. A high coefficient of diameter variation also implies the presence of relatively large trees. These results make sense since productivity is primarily driven by the presence of large trees (Midgley et al. 2002; Midgley \& Seydack 2006; Seydack 2000, 2012).

In studies where forest productivity has been related to area-based variables like forest density, richness and crowding, various effects were found. According to Gamfeldt et al. (2013a,b), there is no clear evidence that species richness is positively correlated with net primary productivity in tropical forests (see also Gillman et al. 2015). However, Morin et al. (2011) found a positive correlation in temperate forests where species richness and productivity are both largely seated in the canopy cohort.

A nonlinear percentile regression was calculated for the remaining two variables, richness and density, to provide an estimate of the maximum production for different levels of richness and density. Maximum basal area production is observed at medium levels of richness (between 18 and 25 species per ha) and density (between 15 and $30 \mathrm{~m}^{2}$ per ha). Highest gross basal area 
productivity levels were sustained in forest parcels/plots with the highest basal area stocking levels (those with the highest basal area accumulation over the preceding period; Seydack 2000). This is congruent with Assmann (1970) who stated that high absolute productivity of mixed stands is usually associated with high growing stock levels. When using basal density classes reflecting the situation at the beginning of the increment period (initial basal area) about 25 years ago, as in this study, particularly plots with initially high basal area stocking levels turned into phases of growing stock reduction caused by the mortality of larger trees. This would explain the lower maximum productivity levels at initial stocking levels above $30 \mathrm{~m}^{2}$ per ha (Fig. 4). This is also in agreement with Midgley \& Seydack (2006) who found that gross production and stocking levels per plot were positively correlated, whereas net production per plot was not correlated with density.

We expect to find the highest species richness in plots where the species-rich forest matrix is not crowded out by canopy-species dominance. However, large canopy trees are underpinning high productivity. At intermediate levels of species richness we expect the forest matrix (contributing most to species richness) to be still intact. Plots containing widely spaced large canopy trees are contributing disproportionately to productivity.

Richness usually refers to the number of tree species per unit of an arbitrary plot area. In this study, we present a method for establishing a common standard, the richness per ha. A three-parameter function, known as the Chapman Richards model (Shifley and Brand, 1984), was used to estimate the species-area relation (SAR), based on drawing 10,000 circular samples for different circle radii between 3 and $58 \mathrm{~m}$. The Chapman Richards model is defined by an asymptote and therefore especially suitable in situations where the contiguous plot area is big enough to capture all species, as in our study. If that is not the case, for example if plot areas are small and the maximum number of species is unknown, a two-parameter power function (Arrhenius, 1921)) would be more appropriate for estimating the SAR (see also He and Legendre, 1996; Tjørve, 2003). The procedure for estimating the species per ha would be based on the same principle as outlined in section Community Structure for the Chapman Richards model. Obviously, the uncertainty in estimating richness will increase with decreasing contiguous plot area.

\section{Effects of neighborhood structures}

As pointed out before, this study is not about classical competition effects (see Seifert et al., 2014), but about the growth of individual trees in response to their specific neighborhood constellation. Although the effects of species diversity on forest productivity has been relatively widely studied, the role of other structural attributes, such as spatial heterogeneity or tree size inequality have received less attention (Bourdier et al. 2016).

Conspecific proximity (within 6 to $8 \mathrm{~m}$ radius) in the Knysna forests had growth-depressing effects, but these were mainly by canopy-occupants exerted on conspecifics of the 10-15 cm diameter cohort (Seydack et al. 2011). Conspecific growth depression manifested itself primarily within the forest matrix and not in the productivity-determining canopy-layer; as would be expected in temperate forests (vide Morin et al. 2011). Mokany et al. (2008), in a controlled study considering 3 species, found that aggregation of species had an effect on growth rate and species resource use, although the effect was variable. In our study some species were unaffected, while in others growth rates increased or decreased (e.g. in Ocotea bullata, notably a species which tends to coppice from existing root stocks).

In studies where aggregation has been considered, at least as an influence on resource use, more clumped cases lead to less efficient resource use (De Boeck et al. 2006; Mokany et al. 2008). It is noteworthy, however, that variables like species diversity and clumping are to some extent linked; in randomly assembled communities, clumps are larger when species diversity is lower (De Boeck et al. 2006). Using data from forest plots across France, considering increments between 2006 and 2011, Bourdier et al. (2016) found that variability in stem size was negatively related to basal area increment for seven out of the ten species investigated. They postulated that this effect could have been the result of reduced light interception and/or reduced light use efficiency, not necessarily merely due to the shade tolerance of the species. If a high variability of tree sizes reflects on the presence of large trees, one could expect high variability to be associated with higher growth rates (as found in this study), i.e. a positive association between high variability and tree-size driven productivity. If high tree size variability is a reflection of the presence of numerous smaller trees, a negative association between variability and productivity may be expected. This would explain what Bourdier et al. (2016) had found for seven of their ten species studied.

Local dominance of reference trees was positively associated with tree growth for all the species studied (Table 2). This result can be expected because of the over-riding importance of large size for individual tree growth, notably in tropical-type forests (see inter alia Clark \& Clark, 1999).

\section{Conclusion}

This contribution presents the first specific analysis of the structure and dynamics of the unique Knysna Afromontane Forest, based on a set of longterm observations. The analysis is hierarchically structured, using a 
theoretical framework for analysing complex natural forests that includes community, plot and neighborhood variables of forest structure and diversity. The community analysis facilitates species grouping while the plotbased variables permit an assessment of the effects of forest density and species richness on productivity. The analysis of neighborboods was found useful for investigating individual tree growth rates. The systematic application of a set of R-scripts may help scientists to analyse their own data sets. This includes a new approach for developing a common standard of tree species diversity for different plot sizes, the species richness per hectare.

\section{Acknowledgement}

We are part of a team of scientific Collaborators of the South African National Parks (SANParks) who kindly provided the Diepwalle FVC data.

\section{Authors' contribution}

KG conceived the study, carried out the calculations and wrote the text with DD, GD and AS; GZ developed most of the required $R$ code.

\section{Competing interests}

The authors declare that they have no competing interests.

\section{Author details}

${ }^{1}$ Georg-August University in Göttingen, Göttingen, Germany. ${ }^{2}$ Department of Forestry and Wood Science, University of Stellenbosch, Stellenbosch, South Africa. ${ }^{3}$ Chinese Academy of Forestry in Beijing, Beijing, China. ${ }^{4}$ South African National Parks, Knysna, South Africa.

\section{Received: 11 May 2016 Accepted: 29 June 2016}

Published online: 26 July 2016

\section{References}

Aguirre O, Hui GY, Gadow K v, Jimenez J (2002) Comparative analysis of natural forest sites in Durango, Mexico. For Ecol Manage 183:137-145

Albert M (1999) Analyse der eingriffsbedingten Strukturveränderung und Durchforstungsmodellierung in Mischbeständen (eng: Analysing Structural Change through Selective Thinning in Mixed Forests). PhD Dissertation University Göttingen, Germany. Hainholz Verlag: 201 pp.

Alder D, Silva JNM (2000) An empirical cohort model for management of Terra Firme forests in the Brazilian Amazon. For Ecol Manage 130(1-3):141-157

Alder D, Oavika F, Sanchez M, Silva JNM, van der Hout P, Wright HL (2002) A comparison of species growth rates from our moist tropical forest regions using increment-size ordination. Int For Rev 4(3):196-205

Arrhenius O (1921) Species and area. J Ecol 9:95-99

Assmann E (1970) The principles of forest yield study. Pergamon, Oxford

Bossel H, Krieger H (1994) Simulation of multi-species tropical forest dynamics using a vertically and horizontally structured model. For Ecol Manage 69:123-144

Bourdier T, Cordonnier T, Kunstler G, Piedallu C, Lagarrigues G, Courbaud B (2016) Tree size inequality reduces forest productivity: an analysis combining inventory data for ten European Species and a Light Competition Model. PLoS One 11(3):e0151852

Castley G (2001) Eastern Cape forests. Retrieved (2001) from: http://zoo.upe.ac.za/ postgrad/guy/ecape.htm.

Caspersen J, Pacala S (2001) Successional diversity and forest ecosystem function. Ecol Res 16:895-903

Clark DA, Clark DB (1999) Assessing the growth of tropical rain forest trees: issues for forest modeling and management. Ecol Appl 9(3):984-997

Cornelissen JHC, Cornwell WK (2014) The Tree of Life in ecosystems: evolution of plant effects on carbon and nutrient cycling. Journal of Ecology 102:269-274.

Corral-Rivas JJ, Wehenkel C, Castellanos BH, Vargas LB, Diéguez-Aranda U (2010) A permutation test of spatial randomness: application to nearest neighbour indices in forest stands. J Forest Res 15:218-225

De Boeck HJ CMHM, Lemmens H, Bossuyt S, Malchair M, Carnol R, Merckx I, Nijs R, Ceulemans (2006) How do climate warming and plant species richness affect water use in experimental grasslands? Plant Soil (2006) 288:249. doi:10.1007/s11104-006-9112-5.
Favrichon V (1994) Classification des especes arborees en groupes fonctionnels en vue de la realisation d'un modele de dynamique de peuplement en foret guyanaise. Rev. É col. (Terre et Vie) 49(4):379-403.

Fraley C, AE Raftery, Murphy TB and Scrucca L. (2012): mclust Version 4 for R: Normal Mixture Modeling for Model-Based Clustering, Classification, and Density Estimation. Technical Report No. 597, Department of Statistics, University of Washington.

Gadow K v (1993) Zur Bestandesbeschreibung in der Forsteinrichtung (Forest Assessment and Description). Forst und Holz 48(21):602-606

Gadow K v (1999) Waldstruktur und Diversität (Forest Structure and Diversity). Allg Forst Jagdzeitung 170(7):117-122

Gadow K v, Zhang CY, Wehenkel C, Pommerening A, Corral-Rivas J, Korol M, Myklush S, Hui GY, Kiviste A, Zhao XH, 2011: Forest Structure and Diversity. In: Pukkala T, Gadow K v 17 (eds.): Continuous Cover Forestry, Book Series Managing Forest Ecosystems Vol 24, (C) Springer Science + Business Media B. V.: p. 29-84.

Gamfeldt L, Snall T, Bagchi R et al (2013a) Higher levels of multiple ecosystem services are found in forests with more tree species. Nat Commun 4(1):1340

Gamfeldt L, Snäll T, Bagchi R, Jonsson M, Gustafsson L, Kjellander P, Mikusiński G (2013b) Higher levels of multiple ecosystem services are found in forests with more tree species. Nat Commun 4:1340

Geldenhuys CJ (2012). Natural forestsand woodlands in South Africa: their classification and distribution. In: Bredenkamp B.V. and Upfold, S.J. (Eds) South African Forestry Handbook. South African Institute of Forestry.

Geldenhuys CJ, MacDevette DR (1989) Conservation status of coastal and montane evergreen forest. In: Huntley BJ (ed) Biotic diversity in southern Africa: concepts and conservation. Oxford University Press, Cape Town, pp 224-238

Gentry AH (1982) Patterns of neotropical plant species diversity. Evol Biol 15:1-84

Gillman LN, Wright SD, Cusens J, McBride PD, Malhi Y, Whittaker RJ (2015) Latitude, productivity and species richness. Glob Ecol Biogeogr 24(1):107-117

Guillemot J, Delpierre N, Vallet P (2014) Assessing the effects of management on forest growth across France: insights from a new functional-structural model. Ann Bot 2014(114):779-793

He F, Legendre P (1996) On species-area relations. Am Nat 148:719-737

Hui GY, Hu YB (2001) Measuring species spatial segregation in mixed forest. For. Res. 14:23-27. doi:10.3321/j.issn:1001-1498.2001.01.004.

Hui G, Zhao X, Zhao Z, Gadow K v (2011) Evaluating tree species spatial diversity based on neighborhood relationships. Forest Sci 57(4):292-300

Köhler P, Ditzer T, Huth A (2000) Concepts for the aggregation of tropical tree species into functional types and the application to Sabah's lowland rain forests. J Trop Ecol 16(4):591-602

Low AB, Rebelo AG (eds) (1996) Vegetation of South Africa, Lesotho and Swaziland. Department of Environmental Affairs and Tourism, Pretoria

Lujan-Soto JE, Corral-Rivas JJ, Aguirre-Calderon OA, Gadow K v (2015) Grouping forest tree species on the Sierra Madre Occidental, Mexico. Allg Forst Jagdzeitung 186(3-4):63-71

Midgley JJ, Seydack AHW (2006) What determines biomass in indigenous forests? An analysys of the Knysna Forest, South Africa. Aust J Bot 54(8):701-705

Midgley JJ, Cowling RM, Seydack AHW, van Wyk GF (1997) Forest. In: Cowling RM, Richardson DM, Pierce SM (eds) Vegetation of Southern Africa. Cambridge University Press, Cambridge, pp 278-299

Midgley JJ, Parker R, Lauri H, Seydack A (2002) Competition among canopy trees in indigenous forests: An analysys of the 'additive basal area' phenomenon. Austral Ecol 27:269-272

Mokany, K., Ash, J., Roxburgh, S. (2008). Functional identity is more important than diversity in influencing ecosystem processes in a temperate native grassland. Journal of Ecology 96:884-893. doi:10.1111/j.1365-2745.2008.01395.x

Morin X, Fahse L, Scherer-Lorenzen M, Bugmann H (2011) Tree species richness promotes productivity in temperate forests through strong complementarity between species. Ecol Lett 14:1211-9. doi:10.1111/j.1461-0248.2011.01691.x PMID: 21955682

Ni R, Baiketuerhan Y, Zhang C, Zhao XH, Gadow K v (2014) Analysing structural diversity in two temperate forests in northeastern China. For Ecol Manage 316:139-148

Picard N, Mortier F, Rossi V, Gourlet-Fleury S (2010) Clustering species using a model of population dynamics and aggregation theory. Ecol Model 221:152-160

Pommerening A (1997) Eine Analyse neuer Ansätze zur Bestandesinventur in strukturreichen Wäldern [An analysis of new approaches towards stand inventory in structure-rich forests]. Ph.D. Faculty of Forestry and Forest Ecology, University of Göttingen, Cuvillier Verlag Göttingen, Dissertation, p 187

Pommerening A (2002) Approaches to quantifying forest structures. Forestry 75:305-324 
Pullan W, Bhadeshia H (eds), (2000) Structure in Science and Art. Cambridge University Press.

Sahney S, Benton MJ, Ferry PA (2010) Links between global taxonomic diversity, ecological diversity and the expansion of vertebrates on land. Biol Lett 6(4):544-547

Seifert T, Seifert S, Seydack A, Durrheim G, Von Gadow K (2014) Competition effects in an afrotemperate forest. Forest Ecosystems 1(1):1-15

Seydack AHW (2000) Theory and practice of yield regulation systems for sustainable management of tropical moist natural forests. In: von Gadow K et al (eds) Sustainable forest management. Kluver Academic Publishers, The Netherlands, pp 257-317

Seydack, A.H.W (2012) Regulation of timber yield sustainability for tropical and subtropical moist forests: Ecosilvicultural paradigms and economic constraints. Chapter 4 in Continuous Cover Forestry. T. Pukkala \& K. Von Gadow (eds.), Managing Forest Ecosystems 23: 129-165.

Seydack AHW, Durrheim G, Louw J (2011) Spatiotemporally interactive growth dynamics in selected South African forests: Edaphoclimatic environment, crowding and climate effects. For Ecol Manage 261:1152-1169

Seydack AHW, Durrheim G, Louw J (2012) Forest structure in selected South African forests: edaphoclimatic environment, phase and disturbance. Eur J Forest Res 131:261-281

Shifley SR, Brand GJ (1984) Chapman-Richards g.rowth function constrained for maximum tree size. Forest Sci 30(5):1066-1070

Tjørve E (2003) Shapes and functions of species-area curves: a review of possible models. J Biogeogr 30:827-835

Van Daalen JC (1991) Forest growth: a 35-year southern Cape study. S Afr Forestry J 159:1-10

Van der Merwe I (1998) The Knysna and Tsitsikamma forests: Their history, ecology and managment. Department of Water Affairs and Forestry, Knysna

Von Breitenbach F (1974) Southern Cape forests and trees: a guide. Government Printer, Pretoria

Watson JL, Liang J, Tobin PC, Lei X, Rentch JS, Artis CE (2015) Large-scale forest inventories of the United States and China reveal positive effects of biodiversity on productivity. Forest Ecosystems 2:22

White $F(1983)$ The vegetation of Africa, a descriptive memoir to accompany the UNESCO/AETFAT/UNSO Vegetation Map of Africa (3 Plates, Northwestern Africa, Northeastern Africa, and Southern Africa, 1:5,000,000). UNESCO, Paris.

Whitmore TC (1991) Tropical rainforest dynamics and its implications for management. In: Gómez-Pompa A, Whitmore TC, Hadley M (eds) Rainforest regeneration and management, vol 6, Man and Biosphere. UNESCO/ Parthenon, Paris, pp 67-89

WWF and IUCN (1994) Centres of plant diversity. A guide and strategy for their conservation. Volume 1. Europe, Africa, South West Asia and the Middle East. IUCN Publications Unit, Cambridge

\section{Submit your manuscript to a SpringerOpen ${ }^{\circ}$ journal and benefit from:}

- Convenient online submission

- Rigorous peer review

- Immediate publication on acceptance

- Open access: articles freely available online

- High visibility within the field

- Retaining the copyright to your article 